\title{
Roles of arbuscular mycorrhizal fungi on acclimatization of clones of Coffea arabica L. produced by somatic embryogenesis
}

\author{
Fungos micorrízicos arbusculares auxiliam na aclimatação de mudas de \\ Coffea arabica L. produzidas por embriogênese somática
}

\author{
Arley José Fonseca ${ }^{1}$ (D) Guilherme Augusto Teixeira Tassone ${ }^{2}$ (D) Marco Aurélio Carbone Carneiro ${ }^{3^{*}}$ (D), \\ Gladyston Rodrigues Carvalho' ${ }^{(D)}$, Carlos Henrique Siqueira Carvalho4 ${ }^{(\mathbb{D})}$, Cesar Elias Botelho' ${ }^{1}$
}

\author{
'Empresa de Pesquisa Agropecuária de Minas Gerais/EPAMIG, Belo Horizonte, MG, Brasil \\ 2Universidade Federal de Lavras/UFLA, Departamento de Agricultura/DAG, Lavras, MG, Brasil \\ 3Universidade Federal de Lavras/UFLA, Departamento de Ciência do Solo/DCS, Lavras, MG, Brasil \\ ${ }^{4}$ Empresa Brasileira de Pesquisa Agropecuária/EMBRAPA, Embrapa Café, Varginha, MG, Brasil \\ *Corresponding author: marcocarbone@ufla.br \\ Received in March 11, 2020 and approved in June 19, 2020
}

\begin{abstract}
The production of Coffea arabica L. clone seedlings through the somatic embryogenesis technique is one of the alternatives of greatest demand for coffee producers. However, clones can face difficulties related to acclimatization carried out under greenhouse conditions, which can increase the production costs. A tested alternative with promising results is inoculation with arbuscular mycorrhizal fungi (AMF) during the seedling acclimatization process. Thus, this study aimed to promote the improvement of the seedling production process through somatic embryogenesis associated with inoculation with AMF. For the production of the clones, seedlings were used in the phase when they presented four pairs of leaves (Clone 1 "Fruiting red Catucaí" and Clone 2 "Acauã"), using "somatic embryogenesis" bioreactors, followed by inoculation with Rhizophagus clarus, Gigaspora margarita and Acaulospora mellea, a mixture of $R$. clarus and $G$. margarita and a mixture of $R$. clarus, G. margarita and A. mellea. After six months, agronomic parameters, leaf nutrient contents and root mycorrhizal colonization were evaluated. The studied clones behaved differently when inoculated with AMFs. Clone 1 showed the best development in the greenhouse, which was determined by the agronomic parameters. Thus, Clone 1 is indicated for the production of vigorous seedlings when associated with inoculation with AMFs.
\end{abstract}

Index terms: Propagation; rooting; clones; mycorrhizae; mineral nutrition.

\begin{abstract}
RESUMO
A produção de mudas de clone de Coffea arabica L. é uma das alternativas de maior demanda para cafeicultores, existindo programas de melhoramento através da técnica de embriogênese somática, no entanto, os clones apresentam dificuldades de pegamento na fase de aclimatação em casa de vegetação elevando custo de produção. Uma alternativa testada com resultados promissores é a inoculação com fungos micorrízicos arbusculares (FMA) durante o processo de aclimatação das mudas. Assim, o objetivo deste trabalho foi promover a melhoria do processo de produção de mudas através de embriogênese somática associada a inoculação com fungos micorrízicos arbusculares. Para a produção dos clones, plântulas foram utilizadas quando apresentaram quatro pares de folhas (clone 1 "Frutificação vermelha Catucaí" e clone 2 "Acauã") produzidos e desenvolvidos em biorreatores "embriogênese somática" e quando levadas para o viveiro inoculadas com Rhizophagus clarus, Gigaspora margarita e Acaulospora mellea, a mistura de R. clarus e G. margarita e a mistura de $R$. clarus, G. margarita e A. mellea. Após seis meses foram avaliados os parâmetros agronômicos, teores de nutrientes foliar e a colonização micorrizica nas raízes. Os clones se comportaram diferentemente quando inoculados com o FMAs, sendo que o clone 1, o que apresentou melhor desenvolvimento no viveiro determinadas pelos parâmetros agronômicos, sendo indicada na produção de mudas clonais vigorosas qu, ando associado a inoculação com fungos micorrízicos arbusculares.
\end{abstract}

Termos para indexação: Propagação; enraizamento; clones; micorrizas; nutrição mineral.

\section{INTRODUCTION}

Coffee is a crop of significant importance for the Brazilian agribusiness. It promotes economic and social development, generating jobs in the coffee producing regions (Embrapa, 2006). The State of Minas Gerais stands out as the largest Brazilian producer of Coffea arabica L., contributing to more than half of the total national production (Conab, 2020). 
Lately, new methods to increase coffee productivity and quality have been pursued by Brazilian coffee growers and researchers. The production of clones of hybrids of C. arabica $\mathrm{L}$. is one of the most promising alternatives (Etienne et al., 2002). Besides the increase of over 30\% in productivity when compared with traditional cultivars, it is also possible to add features of interest more quickly than traditional methods related to the obtention of plant varieties (Bertrand et al., 2005).

As an alternative to the multiplication of $F 1$ hybrids, somatic embryogenesis stands out among the methods of vegetative propagation. Small amounts of source material (leaves) are used for the production of high numbers of clones (Rezende et al., 2012). However, clones of $C$. arabica L. produced via somatic embryogenesis can present some post-laboratory complications, such as the high cost for the production of clones and the difficulties considering their acclimatization (Etienne et al., 2002; Carvalho et al., 2013). Thus, the use of arbuscular mycorrhizal fungi (AMF) in micro-propagated clones of $C$. arabica L. can be a promising technology.

Arbuscular mycorrhizal fungi (AMF), belonging to the phylum Glomeromycota, establish symbiotic mutualistic associations with the roots of most vascular plants (Siqueira et al., 2010). These fungi colonize greater volume of soil due to their mycelium network, increasing the volume of exploited soil and absorption of water and nutrients, especially phosphorus (Maia; Silveira; Cavalcante, 2006; Kahiluoto; Ketoja; Vestberg, 2012; Posada et al., 2018; Rojas et al., 2019). Furthermore, it provides greater resistance to adverse environmental conditions by increasing the post-planting survival and the initial development of coffee trees in the field (Silveira et al., 2003; Souza; Cardoso; Barreto, 2006; Fonseca et al., 2019). The symbiosis also increases the absorption of nutrients such as $\mathrm{P}, \mathrm{Ca}, \mathrm{Mg}, \mathrm{S}$, and $\mathrm{Cu}$ and protects against toxicity of $\mathrm{Mn}$, and $\mathrm{Zn}$ (Saggin-Junior et al., 1995; Saggin-Junior; Siqueira, 1995), promoting greater increments on dry mass and nutrient accumulation (Prates Junior et al., 2019).

The increased efficiency of the production process of clones via somatic embryogenesis using AMF can reduce costs in the production of vigorous coffee seedlings. The use of AMF in coffee seedlings is still little studied, as demonstrated by Cogo et al. (2017) in their systematic review. Therefore, this study aimed to evaluate the contribution of AMF on the acclimation of two clones reproduced by somatic embryogenesis.

\section{MATERIAL AND METHODS}

The experiment was conducted under greenhouse conditions at the experimental nursery of Procafé Foundation, located in Varginha, state of Minas Gerais, Brazil (geographical coordinates $21^{\circ} 34^{\prime} 00^{\prime \prime} S$ and $45^{\circ} 24^{\prime} 22^{\prime \prime} \mathrm{W}$, altitude $=1,000 \mathrm{~m}$ ).

\section{Experimental design, genotypes and arbuscular mycorrhizal fungi}

The experiment was conducted in a completely randomized design with two replications arranged in a 2 $\mathrm{x} 6$ factorial scheme. Two clones of coffee, Clone 1 "Red fruiting Catucaí" and Clone 2 "Acauã", and five AMFs inoculants, F1 (Rhizophagus clarus), F2 (Gigaspora margarita), F3 (Acaulospora mellea), F4 (a mixture of $R$. clarus and G. margarita) and F5 (a mixture of R. clarus, G. margarita, and A. mellea), as well as an uninoculated treatment (F6) were used in the experiment.

The treatments were composed of four repetitions and six clones per each experimental unit. The studied clones were chosen based on their resistance to rust (Hemileia vastatrix), good quality of beverage and high productivity. The genotype Red fruiting Catucaí (Clone 1) originates from the crossing between Icatu and Catuaí and Acauã (Clone 2) originates from the crossing between 'New World 388-17' and 'Sarchimor IAC 1668'.

For the multiplication of AMF, a substrate composed of soil (Dystrophic Red Latosol) and sand at a ratio of $1: 1(\mathrm{v}: \mathrm{v})$ was used. The substrate was sterilized by autoclaving at $120{ }^{\circ} \mathrm{C}$ for 60 minutes and this process was repeated by completing 24 hours. After 20 days, 3-L pots were filled with substrate and seeded with Brachiaria decumbens, which was inoculated separately with spores of $R$. clarus, G. margarita and A. mellea. After cultivation, the spore density of each species was quantified separately, using $50 \mathrm{~mL}$ of sample, followed by wet extraction, according to (Gerdemann; Nicolson, 1963).

\section{Clones and substrate production and fertilization}

The plants used in this study were produced by somatic embryogenesis, according to the protocol described by (Teixeira, 2018). Leaves from the matrix plants that were disinfected were cut into small segments and placed in Petri dishes with culture medium for the induction of embryogenic calluses. The embryogenic calluses were multiplied in a liquid medium under constant agitation, followed by induction to regenerate somatic embryos. The somatic embryos were transferred to temporary immersion 
bioreactors and maintained in this condition until the cotyledon stage. The embryos were grown in pots with culture medium for seedling development. When the clones presented about five centimeters in height and four pairs of leaves, they were transferred to polyethylene tubes of $290 \mathrm{~cm}^{3}$ with an inert substrate composed of thin coconut fiber, and stored under greenhouse conditions to be acclimatized.

The substrate fertilization for the treatments with and without (control) inoculation of AMF was carried out by adding $8.00 \mathrm{~g} \mathrm{dm}^{-3}$ of 14-14-14 fertilizer (N-P-K) of slow-release Osmocote ${ }^{\circledR}$ and $5.00 \mathrm{~g} \mathrm{dm}^{-3}$ of 09-45-11 fertilizer (N-P-K) of Raizal $400^{\circledR}$ to the substrate. At the end of the test, the substrates of the treatments with and without inoculation with AMF were analyzed for their nutrient contents, presenting the following results without fertilization: $1.4 \mathrm{mg} \mathrm{dm}^{-3} \mathrm{P}, 3.3 \mathrm{mg} \mathrm{dm}^{-3} \mathrm{~K}, 3.0 \mathrm{cmol}_{\mathrm{c}} \mathrm{dm}^{-3} \mathrm{Ca}$ and $0.6 \mathrm{cmol}_{\mathrm{c}} \mathrm{dm}^{-3} \mathrm{Mg}$. After fertilization, the substrate presented the following values: $27.3 \mathrm{~g} \mathrm{~kg}^{-1} \mathrm{~N}, 2.3 \mathrm{~g} \mathrm{~kg}^{-1}$ $\mathrm{P}, 14.9 \mathrm{~g} \mathrm{~kg}^{-1} \mathrm{Ca}$ and $3.0 \mathrm{~g} \mathrm{~kg}^{-1} \mathrm{Mg}$.

\section{Inoculation of seedlings}

During the process of pricking, 336 seedlings were transferred from in vitro conduction to tubes of $290 \mathrm{~cm}^{3}$. At the time of transplanting, the clones were inoculated with $50 \mathrm{~mL}$ of AMFs using soil inoculum containing 600 spores, hyphae and colonized roots composed of $R$. clarus, G. margarita, A. mellea, and mixtures of A. clarus $+G$. margarita and $R$. Clarus + G. margarita + A. mellea. The same proportions of spores were applied in the mixtures.

\section{Experiment conduction}

The tubes with the seedlings were placed in a greenhouse equipped with nebulization irrigation system, within 12 hours, on for 20 seconds with a 20 minutes watering shift, and water blade of $0.8 \mathrm{~mm}$, daily. The seedlings remained in the greenhouse for 135 days. After this period, they were transferred to a nursery for acclimatization during 180 days.

The acclimatization of the seedlings was held in nursery equipped with protection on the top and on the sides with $50 \%$ shading screen (Sombrite ${ }^{\circledR}$ ). An automatic intermittent sprinkling irrigation period of 4 hours, connected by 5 minutes with irrigation shift of 5 hours and daily water blade of $6 \mathrm{~mm}$ was used.

After six months, the experiment was evaluated with ClorofiLoG ${ }^{\circledR}$ model CFL 1030 chlorophyll-meter, expressed as Falker Chlorophyll Index (FCI). The leaf areas of the seedlings were also determined (Huerta, 1962). The material was cut and separated into roots and shoots.
The roots were washed in running water for removal of substrates, and fragments of 1 to $2 \mathrm{~cm}$ were stored in $70 \%$ alcohol solution for later determination of the percentage of colonized roots (Giovannetti; Mosse, 1980). The remaining roots as well as the whole aerial part were dried until constant weight in a forced air circulation oven at $65^{\circ} \mathrm{C}$ for the determination of root dry mass (RDM), shoot dry mass (SDM) and total dry mass (TDM).

After determining APDM, shoots were milled in mill type Willey with 40 mesh sieve and digested in sulfuric acid solution for the determination of $\mathrm{N}$ (nitrogen) by micro Kjeldahl method (distillation) and nitro-perchloric solution 2:1 (v:v). The contents of of phosphorus $(\mathrm{P})$ and calcium $(\mathrm{Ca})$ were then determined by colorimetry and atomic absorption spectrophotometry, respectively (Malavolta; Vitti; Oliveira, 1997). The accumulation of nutrients was calculated by multiplying the concentration of nutrients in the aerial part by aerial part dry mass.

\section{Statistical analyzes}

The data were analyzed for normality (Lillierfors test) and homogeneity of variances (Cochran and Barttlet test). The percentages of colonized roots and leaf area were transformed by using $\ln (x+2)$ when a normal distribution was not followed or when the value was inferior to $30 \%$. The variables were submitted to analysis of variance using the $\mathrm{F}$ test at $5 \%$ significance level and the averages of the treatments where compared by the Scott and Knott test at 5\% significance level. Correlation analysis was determined between the variables at 5\% significance level using the Pearson test. All statistical analyses were performed on the statistical analysis system Sisvar (Ferreira, 2011) and SAS program (SAS, 1999), version 9.1.

\section{RESULTS AND DISCUSSION}

The height of the aerial part in Clone 1 inoculated with AMF showed higher values when compared with non-inoculated plants (20.4 and $41.7 \%$, respectively). No significant differences were observed between the treatments in Clone 2. The inoculations of AMF in F1, F2, F3 and F5 in Clone 1 were higher when compared with Clone 2. The stem diameter presented the same trend of the values of height for Clone 1 . The seedlings of this clone inoculated with AMF in F1, F2, F3, F4 and F5 showed increases in stem diameter, ranging from 18.6 to $39.5 \%$ when compared with the control treatment (Table 1). As for the inoculations of AMF in F1, F2 and F3 in Clone 1, stem diameter values were higher than Clone 2. 
Table 1: Shoot height, stem diameter and leaf area of seedlings of two clones of coffee with and without inoculation with arbuscular mycorrhizal fungi carried out under greenhouse conditions in Varginha, MG.

\begin{tabular}{|c|c|c|c|c|c|c|}
\hline \multirow[b]{2}{*}{ Treatments } & \multicolumn{2}{|c|}{ Shoot height } & \multicolumn{2}{|c|}{ Stem Diameter } & \multicolumn{2}{|c|}{ Leaf area } \\
\hline & Clone 1 & Clone 2 & Clone 1 & Clone 2 & Clone 1 & Clone 2 \\
\hline & \multicolumn{2}{|c|}{ ……....cm } & \multicolumn{2}{|c|}{..........mm } & \multicolumn{2}{|c|}{$\ldots \ldots \ldots \ldots . . . \mathrm{m}^{2} \ldots \ldots \ldots$} \\
\hline Control & $12.4 \mathrm{bA}^{1 /}$ & $12.5 \mathrm{aA}$ & $2.5 \mathrm{bA}$ & $2.8 \mathrm{aA}$ & $189.7 \mathrm{bA}$ & $253.2 \mathrm{aA}$ \\
\hline R. clarus & $15.9 \mathrm{aA}$ & $12.3 \mathrm{aB}$ & $3.3 \mathrm{aA}$ & $2.5 \mathrm{aB}$ & $357.8 \mathrm{aA}$ & $164.8 \mathrm{aB}$ \\
\hline G. margarita & $16.5 \mathrm{aA}$ & $12.6 \mathrm{aB}$ & $3.5 \mathrm{aA}$ & $2.7 \mathrm{aB}$ & $385.7 \mathrm{aA}$ & $193.9 \mathrm{aB}$ \\
\hline A. mellea & $17.6 \mathrm{aA}$ & $11.4 \mathrm{aB}$ & $31 \mathrm{aA}$ & $2.3 \mathrm{aB}$ & $376.7 \mathrm{aA}$ & $181.3 \mathrm{aB}$ \\
\hline R. c.; G. m. & $14.9 \mathrm{aA}$ & $13.0 \mathrm{aA}$ & $3.0 \mathrm{aA}$ & $2.9 \mathrm{aA}$ & $294.9 \mathrm{aA}$ & $186.0 \mathrm{aB}$ \\
\hline R. c.; G. m.; A. m. & $17.0 \mathrm{aA}$ & $12.1 \mathrm{aB}$ & $3.0 \mathrm{aA}$ & $2.7 \mathrm{aA}$ & $353.3 \mathrm{aA}$ & $156.5 \mathrm{aB}$ \\
\hline $\mathrm{CV}^{2 \prime}, \%$ & \multicolumn{2}{|c|}{13.4} & \multicolumn{2}{|c|}{14.7} & \multicolumn{2}{|c|}{3.4} \\
\hline
\end{tabular}

${ }_{1 /}$ For each variable, averages followed by the same uppercase letters in the row and lowercase in the column do not differ from each other by the Scott and Knott test at 5\% significance level; ${ }^{2 /}$ Coefficient of variation.

R. c.: Rhizophagus clarus; G. m.: Gigaspora margarita; A. m.: Acaulospora mellea.

The leaf area of Clone 2 with and without inoculation with AMF did not differ among the treatments while Clone 1 presented higher leaf area values for the inoculation treatments when compared with the control treatment. This increase ranged from 55.5 to $103.3 \%$. When comparing the effects of the studied clones, Clone 1 inoculated with AMF in F1, F2, F3, F4 and F5 showed increases when compared with Clone 2.

The present study corroborates with the proposed in the literature for the initial growth of seedlings of coffee, indicative that the AMF species used as inoculants promoted a positive response (Saggin-Júnior et al., 1995). Some authors observed that cultivars of C. arabica $L$. inoculated with species and/or isolates of AMF feature significant increase for the characteristics of height and stem diameter (Bhattacharya; Bagyaraj, 2002; Konrad et al., 2014).

It is clear from these results that there is a positive response to the inoculation of seedlings with AMF, especially for height, stem diameter and leaf area (Table 1). Considering coffee seedlings inoculated with AMF and with low doses of $\mathrm{P}$ in the soil, there was no positive effect on increased leaf area (Siqueira; Collozi-Filho, 1986).

This result is favorable for the plant since it provides benefits such as a greater initial growth of the aerial part, greater photosynthetic rate and larger stem diameter among others. Studies show that AMF promoted increases in the chlorophyll contents in leaves of coffee (Tristão; Andrade; Silveira, 2006).

The results of this study indicate that the species of inoculated AMF affects the response of the plant, corroborating with other studies with AMF in symbiosis with plants (Saggin-Júnior et al., 1995; Moreira et al., 2019).

The total chlorophyll content was higher in seedlings inoculated with $R$. clarus and with $R$. clarus and G. margarita, differing significantly from other the inoculated treatments (Figure 1).

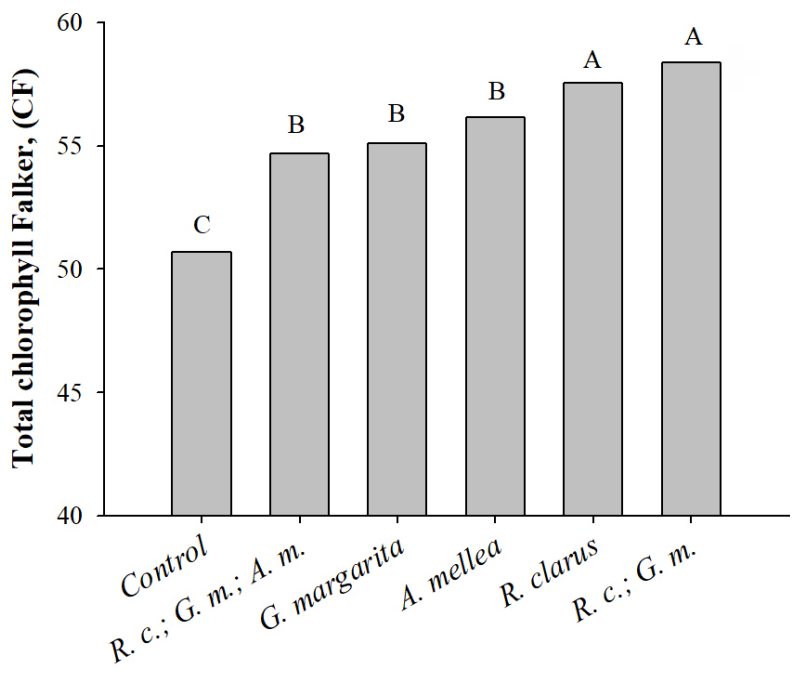

\section{Treatments}

Figure 1: Graphical representation of the averages of the total Falker chlorophyll content of clones of coffee with and without inoculation with arbuscular mycorrhizal fungi carried out under greenhouse conditions in, Varginha MG. R. c.: Rhizophagus clarus; G. m.: Gigaspora margarita; A. m.: Acaulospora mellea. 
Shoot dry mass (SDM), root dry mass (RDM) and total dry mass (TDM) were influenced by fungi and depended on the studied clone (Table 2). For Clone 2, SDM did not differ between the treatments. As for Clone 1, seedlings inoculated with AMF in F2, F3 and F5 showed increases of SDM when compared with the control treatment. When comparing the studied clones, Clone 1 presented higher SDM values than Clone 2 (Table 2).

The root dry mass of Clone 2 did not differ between treatments. As for Clone 1, seedlings inoculated with FMA in F1, F2, F3, F4 and F5 showed increases when compared with the control treatment. Between the studied clones, Clone 1 presented higher values than Clone 2 for the treatments inoculated with FMA in F1, F2, F3 and F5 (Table 2).

For total dry mass, Clone 1 inoculated with AMF in F1, F2, F3, F4 and F5 showed increases when compared with the control treatment (Table 2). Between the studied clones, Clone 1 presented higher values than Clone 2 for the treatments inoculated with FMA in F1, F2, F3 and F5 (Table 2).

The main effects of the studied fungi influenced the accumulations of $\mathrm{N}$ and $\mathrm{P}$. On average, the accumulations of $\mathrm{N}$ on both clones were greater in seedlings inoculated with AMF in F3, F4 and F5 when compared with noninoculated seedlings (control). As for the accumulation of $\mathrm{P}$, the values were higher in seedlings inoculated with AMF in F2, F3, F4 and F5 (Figure 2). The accumulation of $\mathrm{Ca}$ considering the averages of both studied clones was greater in seedlings inoculated with AMF in F5 (Figure 2).

Accordingly, the parameters of vegetative growth and SDM, RDM and TDM promoted satisfactory gains with the inoculation with AMF in Clone 1 (Table 2). Siqueira et al. (1995) obtained similar results in studies using coffee plants inoculated with AMF alone or in combinations, which presented higher values for SDM and RDM when compared with the control treatment.

Other studies corroborate with the results obtained in the present study, in which coffee plants inoculated with several species of AMF increased the absorption of $\mathrm{N}$ and P (Hodge; Campbell; Fitter, 2001). Similar results for the assessed nutrients were observed for $C$. arabica $\mathrm{L}$. inoculated with AMF isolated or in combinations (Fonseca et al., 2019).

Colonization was greater in seedlings inoculated with the mixture differing significantly from the other inoculated treatments. The results of the percentage of colonized roots were satisfactory, since non-inoculated plants (control) failed colonization, and treatment F5, which consisted of three genes or species of AMF, showed the highest percentage of colonization (Figure 3 ). The percentage of colonized roots, the content of chlorophyll and shoot dry mass were influenced only by inoculation with AMF, being observed increments in these variables in the presence of AMF when compared with the control treatment (Figure 3) regardless of the studied clones.

Multiple studies with different genetic materials of coffee plants inoculated with AMF showed variations in the percentage of colonized roots with environmental influence by various biotic and abiotic factors (Siqueira et al., 1995; Flores-Aylas et al., 2003; Costa et al., 2005; Berbara; Souza; Fonseca, 2006; Machineski; Balota; Souza, 2011; Albán; Guerrero; Toro, 2013; Mustafa et al., 2016; Bertolini et al., 2020).

Table 2: Shoot dry mass, root dry mass and total seedling dry mass of two clones of coffee with and without inoculation with arbuscular mycorrhizal fungi carried out under greenhouse conditions in Varginha MG.

\begin{tabular}{|c|c|c|c|c|c|c|}
\hline & \multicolumn{2}{|c|}{ Shoot dry mass } & \multicolumn{2}{|c|}{ Root dry mass } & \multicolumn{2}{|c|}{ Total seedling dry mass } \\
\hline Treatments & Clone 1 & Clone 2 & Clone 1 & Clone 2 & Clone 1 & Clone 2 \\
\hline & \multicolumn{6}{|c|}{ (1) } \\
\hline Control & $2.55 \mathrm{bA}$ & $2.65 \mathrm{aA}$ & $1.41 \mathrm{bA}$ & $1.20 \mathrm{aA}$ & $3.93 \mathrm{bA}$ & $3.78 \mathrm{aA}$ \\
\hline R. clarus & $3.00 \mathrm{bA}$ & $2.55 \mathrm{aA}$ & $2.15 \mathrm{aA}$ & $1.29 \mathrm{aB}$ & $5.17 \mathrm{aA}$ & $3.84 \mathrm{aB}$ \\
\hline G. margarita & $3.28 \mathrm{aA}$ & $2.83 \mathrm{aA}$ & $2.38 \mathrm{aA}$ & $1.63 \mathrm{aB}$ & $5.66 \mathrm{aA}$ & $4.44 \mathrm{aB}$ \\
\hline A. mellea & $3.50 \mathrm{aA}$ & $2.65 \mathrm{aB}$ & $2.42 \mathrm{aA}$ & $1.27 \mathrm{aB}$ & $5.93 \mathrm{aA}$ & $4.02 \mathrm{aB}$ \\
\hline R. c.; G. m. & $2.98 \mathrm{bA}$ & $2.93 \mathrm{aA}$ & $2.32 \mathrm{aA}$ & $1.89 \mathrm{aA}$ & $5.30 \mathrm{aA}$ & $4.80 \mathrm{aA}$ \\
\hline R. c.; G. m.; A. m. & $3.23 \mathrm{aA}$ & $2.68 \mathrm{aB}$ & $2.62 \mathrm{aA}$ & $1.19 \mathrm{aB}$ & $584 \mathrm{aA}$ & $3.86 \mathrm{aB}$ \\
\hline $\mathrm{CV}^{21}, \%$ & \multicolumn{2}{|c|}{10.9} & \multicolumn{2}{|c|}{25.4} & \multicolumn{2}{|c|}{13.8} \\
\hline
\end{tabular}

${ }^{1 /}$ For each variable, averages followed by the same uppercase letters in the row and lowercase in the column do not differ from each other by the Scott and Knott test at $5 \%$ significance level; ${ }^{21}$ Coefficient of variation.

R. c.: Rhizophagus clarus; G. m.: Gigaspora margarita; A. m.: Acaulospora mellea. 

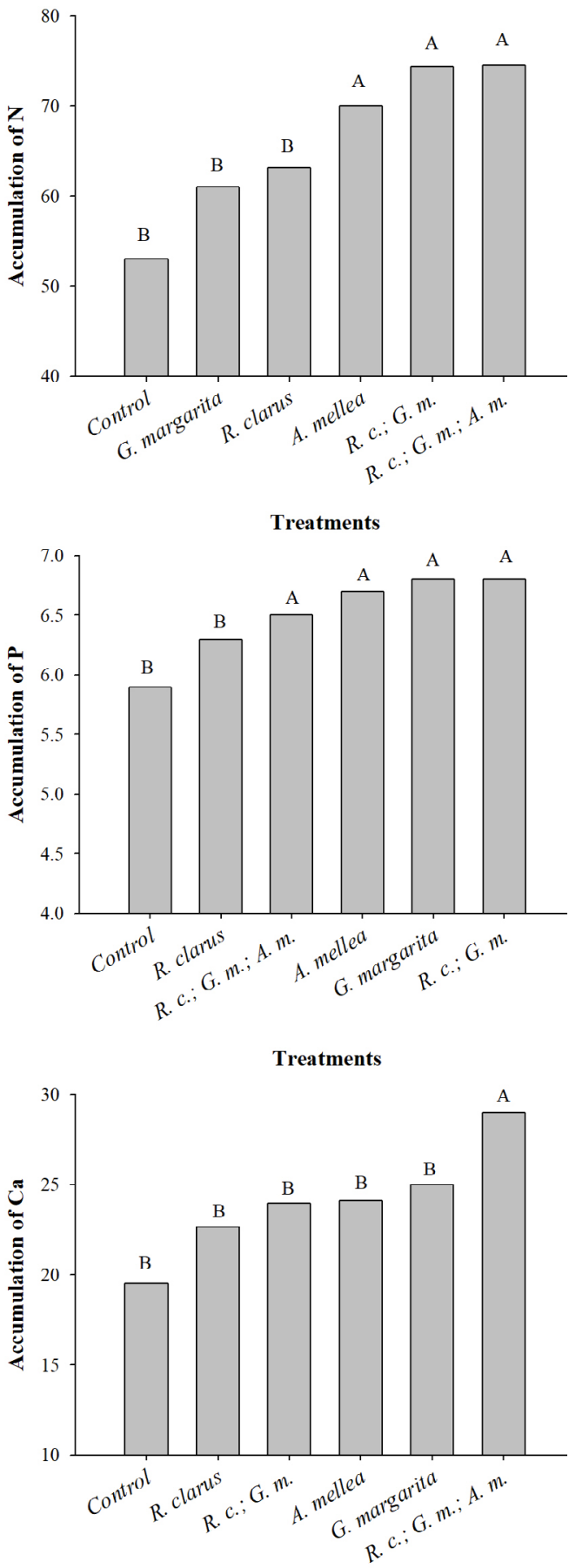

Treatments

Figure 2: Graphical representation of the average accumulation of N, P and $\mathrm{Ca}$ in seedlings of clones of coffee with and without inoculation with arbuscular mycorrhizal fungi carried out under greenhouse conditions in Varginha MG. R. c.: Rhizophagus clarus; G. m.: Gigaspora margarita; A. m.: Acaulospora mellea.

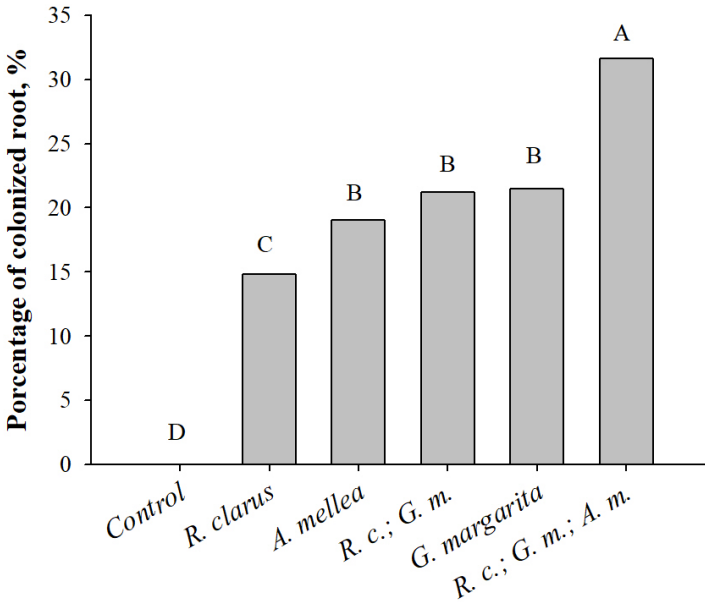

Treatments

Figure 3: Average values of percentage of colonized roots of seedlings of two clones of coffee with and without inoculation of arbuscular mycorrhizal fungi carried out under greenhouse conditions in Varginha, MG. R. c.: Rhizophagus clarus; G. m.: Gigaspora margarita; A. m.: Acaulospora mellea.

Another important point to be explored is how the species and genes of AMF used in the controlled inoculation. Moreira et al. (2019) studied Gigaspora margarita and Rhizophagus clarus and observed an increase to shoot dry mass and root system when compared with the noninoculated treatment. Therefore, the species of AMF affect positively the answer of the plant and present a positive point regarding programs of controlled use of AMF. It is necessary the use of effective inoculants that are adapted to the soil, climate conditions and culture management.

Tristão, Andrade and Silveira (2006), evaluating Yellow Catuaí seedlings IAC 62 inoculated with AMF in different substrates, observed a wide variation in the percentage of roots colonized with values ranging from 3.1 to $39.1 \%$. The values are similar to the results of the present study.

Therefore, the parameters of growth in height, stem diameter, shoot and root dry mass, total leaf area, chlorophyll content and total deposits of N, P and Ca were positively affected by inoculation of AMF in at least one of the studied clones, showing greater effects when compared with groups of non-inoculated seedlings. This fact observed on the results obtained in this study where significant positive correlation was found between mycorrhizal colonization, root dry mass, total dry mass and accumulation of $\mathrm{Ca}$ (Table 3 ) in Clone 1 contributed to the development of the plant due to the increased absorption of nutrients, especially $\mathrm{Ca}$. On the other hand, Clone 2 did not present this effect. 
Table 3: Clone correlation between the percentage of colonization, height, stem diameter, shoot dry mass, root dry mass, total dry mass, leaf area, chlorophyll content and accumulation of N, P and Ca for seedlings of coffee with and without the use of arbuscular mycorrhizal fungi on a greenhouse experiment, Varginha MG.

\begin{tabular}{|c|c|c|c|c|c|c|c|c|c|c|}
\hline Correlation & $\%$ colonization & Height & $\begin{array}{c}\text { Stem } \\
\text { diameter }\end{array}$ & $\begin{array}{c}\text { Shoot } \\
\text { dry mass }\end{array}$ & $\begin{array}{l}\text { Root dry } \\
\text { mass }\end{array}$ & $\begin{array}{c}\text { Total dry } \\
\text { mass }\end{array}$ & $\begin{array}{l}\text { Leaf } \\
\text { area }\end{array}$ & $\begin{array}{l}\text { Chlorophyll } \\
\text { content }\end{array}$ & Nitrogen & Phosphorus \\
\hline \multicolumn{11}{|l|}{ Clone 1} \\
\hline Height & $0.734 n s$ & & & & & & & & & \\
\hline Stem diameter & $0.500 \mathrm{~ns}$ & $0.695 \mathrm{~ns}$ & & & & & & & & \\
\hline $\begin{array}{l}\text { Aerial part dry } \\
\text { mass }\end{array}$ & $0.661 \mathrm{~ns}$ & $0.967 * \star$ & $0.655 n s$ & & & & & & & \\
\hline Root dry mass & $0.944 * \star$ & $0.911 *$ & $0.644 \mathrm{~ns}$ & $0.867^{\star}$ & & & & & & \\
\hline Total dry mass & $0.848^{*}$ & $0.968 * *$ & $0.671 \mathrm{~ns}$ & $0.957 * \star$ & $0.974 * \star$ & & & & & \\
\hline Leaf area & $0.687 n s$ & $0.955 * *$ & $0.875^{\star}$ & $0.911 *$ & $0.867 *$ & $0.917 *$ & & & & \\
\hline $\begin{array}{c}\text { Chlorophyll } \\
\text { content }\end{array}$ & $0.402 \mathrm{~ns}$ & $0.395 \mathrm{~ns}$ & $0.710 \mathrm{~ns}$ & $0.357 \mathrm{~ns}$ & $0.459 \mathrm{~ns}$ & $0.429 n s$ & $0.548 \mathrm{~ns}$ & & & \\
\hline Nitrogen & $0.782 \mathrm{~ns}$ & $0.564 \mathrm{~ns}$ & $0.312 \mathrm{~ns}$ & $0.564 \mathrm{~ns}$ & $0.761 \mathrm{~ns}$ & $0.698 \mathrm{~ns}$ & $0.487 n s$ & $0.635 n s$ & & \\
\hline Phosphorus & $0.673 n s$ & $0.893^{*}$ & $0.795 \mathrm{~ns}$ & $0.941 * *$ & $0.855^{*}$ & $0.924 * \star$ & $0.913^{*}$ & $0.602 \mathrm{~ns}$ & $0.653 \mathrm{~ns}$ & \\
\hline Calcium & $0.858^{*}$ & $0.724 \mathrm{~ns}$ & $0.246 n s$ & $0.640 \mathrm{~ns}$ & $0.830^{*}$ & $0.772 \mathrm{~ns}$ & $0.586 n s$ & $-0.063 n s$ & $0.488 n s$ & $0.480 \mathrm{~ns}$ \\
\hline \multicolumn{11}{|l|}{ Clone 2} \\
\hline Height & $-0.262 n s$ & & & & & & & & & \\
\hline Stem diameter & $-0.184 n s$ & $0.849 *$ & & & & & & & & \\
\hline $\begin{array}{l}\text { Aerial part dry } \\
\text { mass }\end{array}$ & $0.205 \mathrm{~ns}$ & $0.610 \mathrm{~ns}$ & $0.603 n s$ & & & & & & & \\
\hline Root dry mass & $0.093 \mathrm{~ns}$ & $0.693 n s$ & $0.462 \mathrm{~ns}$ & $0.907 *$ & & & & & & \\
\hline Total dry mass & $0.133 n s$ & $0.680 \mathrm{~ns}$ & $0.519 \mathrm{~ns}$ & $0.957 * \star$ & $0.990 * *$ & & & & & \\
\hline Leaf area & $-0.831 *$ & $0.247 \mathrm{~ns}$ & $0.395 \mathrm{~ns}$ & $0.058 \mathrm{~ns}$ - & $-0.057 n s$ & $-0.020 n s$ & & & & \\
\hline $\begin{array}{l}\text { Chlorophyll } \\
\text { content }\end{array}$ & $0.667 n s$ & $-0.072 n s$ & $-0.229 n s$ & $0.273 n s$ & $0.397 \mathrm{~ns}$ & $0.364 \mathrm{~ns}$ & -0.851 * & & & \\
\hline Nitrogen & $0.839 *$ & $-0.264 n s$ & $-0.065 n s$ & $0.162 \mathrm{~ns}$ & $0.020 \mathrm{~ns}$ & $0.068 \mathrm{~ns}$ & $-0.748 n s$ & $0.762 \mathrm{~ns}$ & & \\
\hline Phosphorus & $0.495 \mathrm{~ns}$ & $0.346 \mathrm{~ns}$ & $0.368 \mathrm{~ns}$ & $0.911 *$ & $0.814^{*}$ & $0.864 *$ & $-0.278 n s$ & $0.601 \mathrm{~ns}$ & $0.518 \mathrm{~ns}$ & \\
\hline Calcium & $0.645 \mathrm{~ns}$ & $0.370 \mathrm{~ns}$ & $0.115 \mathrm{~ns}$ & $0.631 \mathrm{~ns}$ & $0.726 \mathrm{~ns}$ & $0.710 \mathrm{~ns}$ & $-0.600 n s$ & $0.606 \mathrm{~ns}$ & $0.339 \mathrm{~ns}$ & $0.690 \mathrm{~ns}$ \\
\hline
\end{tabular}

* and ** 5 and $1 \%$ significance level, respectively. ns not significant by the Pearson test.

Other authors have observed similar results for cultivars of $C$. arabica $\mathrm{L}$. inoculated with $\mathrm{AMF}$ isolated or in combinations (Tristão; Andrade; Silveira, 2006; Sammaurina et al., 2020). When plants are colonized with AMF, they generally do not show signs of deficiency. Moreover, they present better field adaptation aspects, such as survival and initial growth (Surpano et al., 2015; Prates Junior et al., 2019). There, the effectiveness of using AMF for the formation of coffee seedlings in nursery environments can be transferred to a most advanced phase of development of the coffee plants. Furthermore, another point to be noted is the quality and mineral nutrition of plants, providing greater vigor and greater productivity of coffee plants.

\section{CONCLUSIONS}

The use of AMF improved the development of micro-propagated seedlings of Coffea arabica $\mathrm{L}$. in the phase of acclimatization. The studied clones presented different behaviors when inoculated with AMF. Clone 1 (red fruiting Catucaí) showed better ability to be used in the production of micro-propagated seedlings using AMF.

\section{ACKNOWLEDGMENTS}

The authors acknowledge FAPEMIG for the financial support, $\mathrm{CNPq}$ for the productivity scholarships 
(G.R.C. and M.A.C.C.), CAPES, INCT and the Brazilian Consortium for Coffee Research (EMBRAPA/UFLA).

\section{REFERENCES}

ALBÁN, R.; GUERRERO, R.; TORO, M. Interactions between a root Knot nematoide (Meloidoyne exigua) and arbuscular mycorrhizae in coffee plant development (Coffea arabica). American Journal of Plant Sciences, 4:19-23, 2013.

BerbarA, R. L. L.; SOUZA, F. A.; FONSECA, H. M. A. C. Fungos Micorrízicos arbusculares: Muito além da nutrição, In: FERNANDES, M. S. Nutrição mineral de plantas. Viçosa, MG: Sociedade Brasileira de Ciência do Solo; 2006. 432p.

BERTRAND, B. et al. Coffea arabica hybrid performance for yield, fertility, and bean weight. Euphytica, 141:255-262, 2005.

BERTOLINI, V. et al. Diversidad de hongos micorrizógenos arbusculares en plantaciones de café (Coffea arabica) del volcán Tacaná, Chiapas, México. Acta Botanica Mexicana, 127:e1602, 2020.

BHATTACHARYA, S.; BAGYARAJ, D. J. Effectiveness of arbuscular mycorrhizal fungal isolates on arabica coffee (Coffea arabica L.). Biological Agriculture \& Horticulture, 20(2):125-131, 2002.

CARVALHO, C. H. S. et al. Custo de produção de mudas clonais de café arábica produzidas por embriogênese somática. Brasília: Embrapa, 3: 1-10, 2013. (Circular Técnica).

COGO, F. D. et al. Arbuscular mycorrhiza in Coffea arabica L.: Review and meta-analysis. Coffee Science, 12(3):419-443, 2017.

COMPANHIA NACIONAL DE ABASTECIMENTO - CONAB. Levantamento CONAB da safra de café. Brasília, DF: CONAB, 2020. Available in: <https://www.conab.gov.br/ info-agro/safras/cafe/boletim-da-safra-de-cafe>. Access in: june, 22, 2020.

COSTA, C. M. C. Et al. Fungos micorrízicos arbusculares e adubação fosfatada em mudas de mangabeira. Pesquisa Agropecuária Brasileira, 40(3):225-232, 2005.

EMPRESA BRASILEIRA DE PESQUISA AGROPECUÁRIA EMBRAPA. Informação tecnológica. Brasília, DF: EMBRAPA, 2006. Available in: <http://www.sapc.embrapa. br/arquivos/consorcio/publicacoes_tecnicas/Livro_Rufino_ PNP\&D_Cafe.pdf>. Access in: June, 21, 2020.

ETIENNE, $H$. et al Biotechnological application for the improvement of coffee (Coffea arabica L.). In Vitro Cellular \& Developmental Biology - Plant, 38:129-138, 2002.
FERREIRA, D. F. Sisvar: A computer statistical analysis system. Ciência e Agrotecnologia, 35(6):1039-1042, 2011.

FONSECA, A. J. et al. Arbuscular mycorrhizal fungus on the initial growth, and nutrition of Coffea arabica L. genotypes. Ciência e Agrotecnologia, 43:e006919, 2019.

FLORES-AYLAS, W. W. et al. Efeito de Glomus etunicatum e fósforo no crescimento inicial de espécies arbóreas em semeadura direta. Pesquisa Agropecuária Brasileira, 38(2):257-266, 2003.

GERDEMANN, J. W.; NICOLSON, T. H. Spores of mycorrhizal endogone species extracted from soil by wet-sieving, and decanting. Transactions of the British Mycological Society, 46(2):235-244, 1963.

GIOVANNETTI, M.; MOSSE, B. An evaluation of techniques for measuring vesicular-arbuscular mycorrhizal infection in roots. New Phytologist, 84(3):489-500, 1980.

HODGE, A.; CAMPBELL, C. D.; FITTER, A. H. An arbuscular mycorrizal fungi accelerates decomposition, and acquires nitrogen directiy from organic material. Nature, 413(20):297-299, 2001.

HUERTA, S. A. Comparación de métodos de laboratorio y de campo para medir elareadelcafeto. Cenicafé, 13(1):33-42, 1962.

KAHILUOTO, H.; KETOJA, E.; VESTBERG, M. Plant-available P supply is not the main factor determining the benefit from arbuscular mycorrhiza to crop $\mathrm{P}$ nutrition and growth in contrasting cropping systems. Plant and Soil, 350(1):8598, 2012.

KONRAD, M. L. F. et al. Resposta do cafeeiro à inoculação de fungos micorrízicos arbusculares em Latossolo Vermelho de cerrado. Bioscience Journal, 30(4):933-941, 2014.

MACHINESKI, O.; BALOTA, E. L.; SOUZA, J. R. P. Resposta da mamoneira a fungos micorrízicos arbusculares e a níveis de fósforo. Semina: Ciências Agrárias, 32(suplemento 1):1855-1862, 2011.

MAIA, L. C.; SILVEIRA, N. S. S.; CAVALCANTE, U. M. T. Interaction between arbuscular mycorrhizal fungi, and root pathogens, In: RAI, M. K. (Ed.). Handbook of microbial biofertilizers. New York: The Haworth, 2006. 610p.

MALAVOlTA, E.; VITTI, G. C.; OLIVEIRA, S. A. Avaliação do estado nutricional das plantas: Princípios e aplicações. 2nd ed. Piracicaba: POTAFOS; 1997. 319p.

MOREIRA, S. D. et al. Arbuscular mycorrhizal fungi, and phosphorus doses on coffee growth under a non-sterile soil. Revista Caatinga, 32(1):72-80, 2019. 
MUSTAFA, G. et al. Phosphorus supply, arbuscular mycorrhizal fungal species, and plant genotype impact on the protective efficacy of mycorrhizal inoculation against wheat powdery mildew. Mycorrhiza, 26(7):685-697, 2016.

POSADA, R. H et al. Effects of soil physical and chemical parameters, and farm management practices on arbuscular mycorrhizal fungi communities, and diversities in coffee plantations in Colombia and Mexico. Agroforestry Systems, 92(2):555-574, 2018.

PRATES JUNIOR, P. et al. Agroecological coffee management increases arbuscular mycorrhizal fungi diversity. PLoS One, 14(1):e0209093, 2019.

REZENDE, J. C. et al. Multiplication of embryogenic calli in Coffea arabica L. Acta Scientiarum. Agronomy, 34(1):93-98, 2012.

ROJAS, Y. D. C. P. et al. Effects of native arbuscular mycorrhizal, and phosphate-solubilizing fungi on coffee plants. Agroforestry Systems, 93(3):961-972, 2019.

SAGGIN-JÚNIOR, O. J.; SIQUEIRA, J. O. Avaliação da eficiência simbiótica de fungos endomicorrízicos para o cafeeiro. Revista Brasileira de Ciência do Solo, 19:221-228, 1995.

SAGGIN-JÚNIOR, O. J. et al. Colonização do cafeeiro por diferentes fungos micorrízicos: Efeito na formação das mudas e no crescimento em solo fumigado. Revista Brasileira de Ciência do Solo, 19:213-220, 1995.

SILVEIRA, A. P. D. et al. Desenvolvimento de fungos micorrízicos arbusculares na produção de mudas de maracujazeiroamarelo, em diferentes substratos. Bragantia, 62(1):8999, 2003.
SAMMAURIA, R. et al. Microbial inoculants: Potential tool for sustainability of agricultural production systems. Archives of Microbiology, 202:677-693, 2020.

SAS. SAS Software. Version 9.1. CAry, Noth Carolina: SAS Institute Inc., 1999.

SIQUEIRA, J. O.; COLLOZI-FILHO, A. A. Micorrizas vesículoarbusculares em mudas de cafeeiro. II. Efeito do fósforo no estabelecimento e funcionamento da simbiose. Revista Brasileira de Ciência do Solo, 10(3):207-211, 1986.

SIQUEIRA, J. O. et al. Influência do substrato de formação e da micorriza no crescimento de mudas de cafeeiro transplantadas. Pesquisa Agropecuária Brasileira, 30(12):1417-1425, 1995.

SIQUEIRA, J. O. et al. Micorrizas: 30 anos de pesquisa no Brasil. Lavras: Editora UFLA. 2010. 716p.

SOUZA, V. C.; CARDOSO, G. D.; BARRETO, A. F. Estudo sobre fungos micorrízicos. Revista Brasileira de Engenharia Agrícola e Ambiental, 10(3): 612-618, 2006.

SUPARNO, A. et al. Inoculation of arbuscular mycorrhizal fungi increase the growth of cocoa, and coffee seedling applied with Ayamaru Phosphate Rock. Journal of Agricultural Science, 7(5):199-210, 2015.

TEIXEIRA, J. B. Mudas clonais de café: Produção por meio de embriogênese somática. EMBRAPA, 2018, 187p.

TRISTÃO, F. S. M.; ANDRADE, S. A. L.; SILVEIRA, A. P. D. Fungos micorrízicos arbusculares na formação de mudas de cafeeiro e substrato orgânico comerciais. Bragantia, 65(4):649-658, 2006. 